\title{
Campylobacter like organisms on the gastric mucosa: culture, histological, and serological studies
}

\author{
DM JONES, ${ }^{*}$ AM LESSELLS, $\dagger$ JOAN ELDRIDGE* \\ From the *Public Health Laboratory and the †Department of Histopathology, Withington Hospital, \\ Manchester M20 8LR
}

SUMMARY Biopsy samples were taken from the gastric mucosa of 50 patients attending a gastroscopy clinic; blood was also taken for serological studies. A campylobacter like organism was grown from 31 patients $(62 \%)$ and the organism was seen in sections from 27 biopsies. Antibody was found in 31 patients by complement fixation and in 27 by bacterial agglutination. There were strong positive correlations between the presence of the organism, detectable antibody, and histological gastritis. Antibody to the campylobacter like organism was comparatively uncommon in patients without gastritis and in samples from blood donors and antenatal patients.

In 1940 Freedberg and Barron, ${ }^{1}$ using silver staining techniques, found spirochaetes in the gastric mucosa of 13 of 35 patients who underwent partial gastric resection for ulcers or carcinoma. The organisms were rarely seen in the absence of ulceration. More recently, the presence of unidentified curved bacilli on the gastric mucosa of patients attending for gastroscopy was reported by Warren ${ }^{2}$ and Marshall, ${ }^{3}$ also using silver stains. The presence of these organisms was associated with histologically demonstrable gastritis. From some of the patients they isolated the organism on moist chocolate agar incubated at $37^{\circ} \mathrm{C}$ in a microaerophilic atmosphere suitable for the growth of Campylobacter jejuni. These bacteria had a superficial morphological resemblance to the known species of campylobacter, but with up to five sheathed flagella arising from one end of the organism. The importance of the presence of these bacteria in the stomach is uncertain. We report here the results of a study of 50 consecutive patients attending a gastroscopy clinic. We have extended the original observations by using serological methods to detect antibody at the same time as examining the material by culture and histology.

\section{Material and methods}

Biopsies were taken from the antral mucosa of each patient undergoing gastroscopy. Samples were placed in formalin for histology and in nutrient broth (Oxoid No 2 CM67) for transmission to the

Accepted for publication 23 May 1984 microbiology laboratory. Specimens were cultured within $2 \mathrm{~h}$ of collection. A sample of serum for antibody tests was collected from each patient. For comparison, serum from blood donors and antenatal patients was also examined.

\section{PATIENTS}

The indications for gastroscopy were symptoms referable to the upper gastrointestinal tract. On gastroscopy, most patients had evidence of ulceration or gastritis; about one third had no abnormality. Only one patient had a carcinoma. The average age of the patients was 53 years (range 19-78).

\section{MICROSCOPY AND CULTURE}

Each fresh endoscopic biopsy was rubbed over a microscope slide and the surface of a blood agar plate (Blood Agar Base No 2, Oxoid CM271, containing 7\% defibrinated horse blood (Tissue Culture Services)). The blood agar plate was incubated for four days at $37^{\circ} \mathrm{C}$ in an atmosphere of $10 \% \mathrm{CO}_{2}$, $5 \% \mathrm{O}_{2}$, and $85 \% \mathrm{H}_{2}$. The smear on the glass slide was heat fixed and stained by Gram's method.

\section{HISTOLOGY}

The endoscopic biopsies of gastric antral mucosa for histological examination were fixed in Carson's neutral buffered formalin and routinely processed. Sections were stained with haematoxylin and eosin in all cases and some sections from initial biopsies were also stained using the Gram, periodic acid Schiff, Giemsa, and Warthin Starry techniques to aid identification of the organism histologically. It 
soon became apparent, however, that careful examination of the haematoxylin and eosin sections using a $\times 40$ objective or an oil immersion lens was sufficient to identify the organism. The presence or absence of gastritis was assessed using standard criteria, ${ }^{4}$ and the cases were divided into superficial or atrophic gastritis and into active or inactive phases. Often the division into superficial or atrophic gastritis was difficult as the biopsies did not always represent the full thickness of the gastric mucosa. The diagnosis of atrophic gastritis was therefore based largely on the presence of intestinal metaplasia. The biopsies were assessed histologically on three separate occasions several weeks apart.

\section{SEROLOGY}

A complement fixation test was developed using a sonicate $(20 \mathrm{kHz}, 20 \mathrm{cycles} / \mathrm{s}$ for $5 \mathrm{~min})$ of a thick suspension of organisms, harvested from a three day culture on a blood agar plate, as antigen. Complement fixation tests for antibody to $C$ jejunis ${ }^{5}$ were also performed on the sera. Agglutination tests with formolised bacterial suspensions, made from a mixture of six isolates, were made in the conventional way.

\section{Results}

\section{CULTURE}

The campylobacter like organism was grown from $31(62 \%)$ of the 50 patients' specimens examined, and was seen in direct Gram films of mucus from 26 $(52 \%)$ patients. These organisms had characteristic single or double curves and were easily identified in smears of mucus. They did not appear to be closely attached to gastric mucosal cells. After three or four days' incubation they grew as grey, translucent convex colonies varying from $0.5 \mathrm{~mm}$ to $1 \mathrm{~mm}$ in diameter. Sometimes faint haemolysis of the blood in the medium was produced. Gram films of this growth showed typical curved morphology (Figs. 1 and 2). There were occasional minor colonial differences between the strains, but in general the colonies from the different isolates looked similar. The organisms showed a degree of oxygen sensitivity in that subculture after more than $2 \mathrm{~h}$ on the bench was sometimes unsuccessful. There was no growth in peptone water or nutrient broth and the bacteria were oxidase and catalase positive, motile, and grew only at $37^{\circ} \mathrm{C}$. By the disc technique they were susceptible to discs containing the following concentrations $(\mu \mathrm{g} / \mathrm{ml})$ of antibiotic: penicillin (1), tetracycline (10), erythromycin (5), gentamicin (10), ampicillin (2), and metronidazole (5). They were resistant to sulphonamides (200), trimethoprim

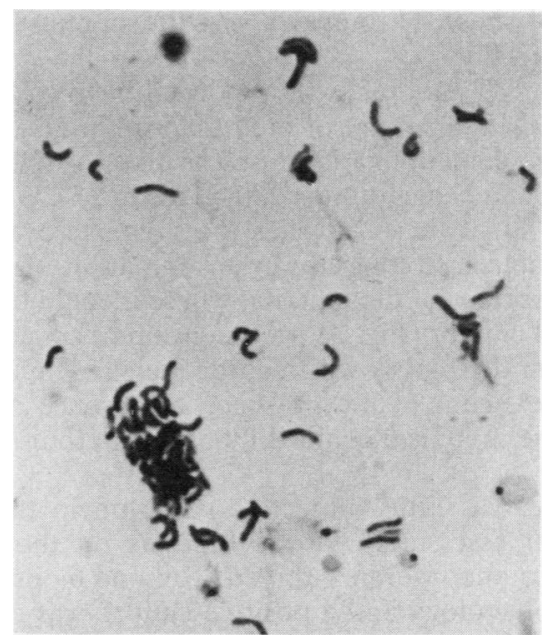

Fig. 1 Gram film of culture of campylobacter like organism. $\times 1280$.

$(2 \cdot 5)$, and nalidixic acid (30).

\section{HISTOLOGY}

Of the 50 biopsies, six were inadequate. Two of the specimens consisted of only superficial fragments, in two duodenal mucosa was present, and in two there was appreciable crush artefact. Of the remaining 44 biopsies, 15 were normal and 29 were abnormal. There were 16 biopsies with active superficial gastritis, eight with inactive superficial gastritis, four with active atrophic gastritis, and one with inactive atrophic gastritis. Of the 15 cases with normal histology, there was only one patient with a positive culture; antibody was also present. One other patient had a complement fixation titre of $1 / 2$. In

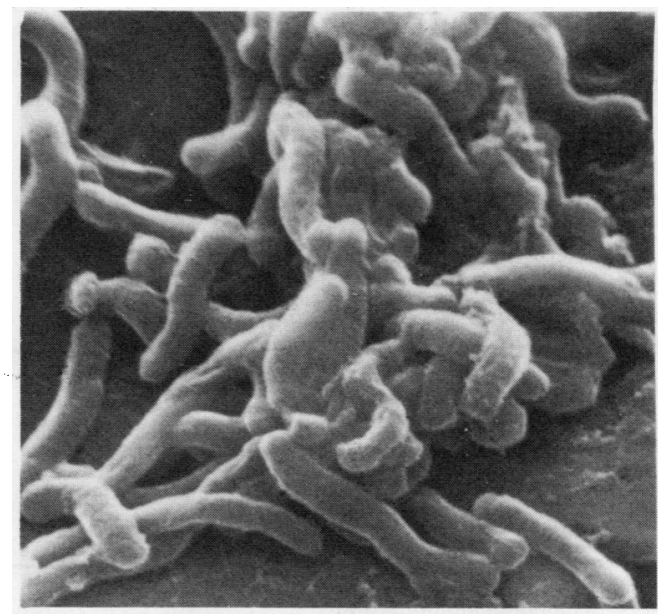

Fig. 2 Scanning electronmicrograph $\times 16000$. 
none of these 15 biopsies was the organism seen histologically.

In the 29 patients with abnormal histology there was a positive culture of the organism in $26(90 \%)$. The complement fixation test was also positive in 26 $(90 \%)$, and $\mathrm{H}$ agglutinins detectable in $23(79 \%)$. In $23(79 \%)$ of these biopsies the organism was also identifiable histologically by examination of mucin on the surface of the mucosa, where it could be seen in small clumps (Fig. 3). In the group of six patients in whom the biopsy was regarded as inadequate for the assessment of the presence or absence of gastritis, the organism could still be seen in four (Table 1).

There was little subjective variation in the histological assessment of the biopsies on the three occasions they were examined. The one biopsy with normal histology and a positive culture was classed as normal on two occasions and as mild inactive superficial gastritis on the other.

The organism was shown to be present, whether by culture or by raised antibody titres, in a similar proportion of cases of active gastritis and inactive gastritis. Similarly, there was no significant difference when the cases were divided into superficial and atrophic gastritis. There appeared to be no obvious correlation between the degree of the gastritis and the titre of the antibody response.

\section{SEROLOGY}

The results obtained in the complement fixation test with hyperimmune rabbit sera raised against the campylobacter like organism, and also with antisera against $C$ jejuni, showed that there are some serological relations between these organisms. A one way cross reaction was observed in that antisera to $C$ jejuni reacted with the antigen made from the campylobacter like organism, but not vice versa (Table 2 ). Cross reactions were only occasionally seen with human convalescent sera. Of the 34 positive sera in this study, only six also reacted with the $C$ jejuni antigen, but this was to a much lower titre. No such cross reactions were observed with the $\mathrm{H}$ agglutination test. There were no cross reactions in the tests

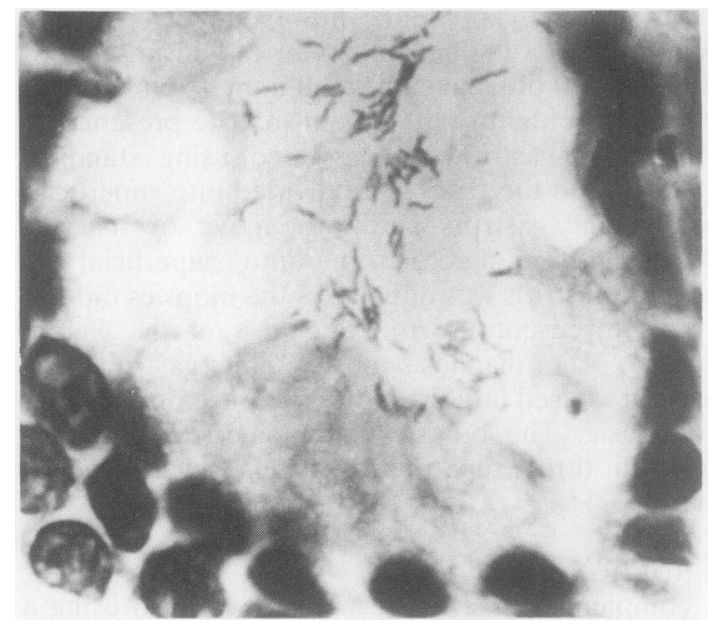

Fig. 3 Gastric mucosa. Haematoxylin and eosin. Original magnification $\times 1280$.

with sera from blood donors and antenatal patients.

Of the 50 patients studied, $31(62 \%)$ had complement fixing antibody and $27(54 \%)$ had $\mathrm{H}$ agglutinins. The presence of antibody detected by either method correlated highly with a positive culture (Table 3 ). In three of the patients who had antibody but who were culture negative, the organisms were seen in the sections and represent culture failures owing to overgrowth of the campylobacter like organism by more rapidly growing contaminants on the unselective medium used.

The antibody titres in patients with and without gastritis are shown in Table 4 . The strong correlation between the absence of antibody, negative culture, and normal histology led us to look at subjects other than those with gastric symptoms. The results obtained with sera from antenatal patients and sera from blood donors are shown in Table 5.

\section{Discussion}

This study has shown a strong positive correlation between histological gastritis, whether active, inactive, superficial, or atrophic, and the presence of spiral organisms, whether seen histologically (79\%)

Table 1 Antral biopsies, culture, and serological results

\begin{tabular}{|c|c|c|c|c|c|}
\hline Histology & No of biopsies & $\begin{array}{l}\text { Organisms seen } \\
(H \text { and } E)\end{array}$ & Organisms grown & $C F T>2^{*}$ & Agglutination $\geqslant 10^{*}$ \\
\hline $\begin{array}{l}\text { Normal } \\
\text { Superficial gastritis } \\
\text { Atrophic gastritis } \\
\text { Inadequate } \\
\text { Total }\end{array}$ & $\begin{array}{r}15 \\
24 \\
5 \\
6 \\
50\end{array}$ & $\begin{array}{r}0 \\
20 \\
3 \\
4 \\
27\end{array}$ & $\begin{array}{r}1 \\
21 \\
5 \\
4 \\
31\end{array}$ & $\begin{array}{r}2 \\
22 \\
4 \\
3 \\
31\end{array}$ & $\begin{array}{r}1 \\
19 \\
4 \\
3 \\
27\end{array}$ \\
\hline
\end{tabular}

CFT = complement fixation titre.

$\mathrm{H}$ and $\mathrm{E}=$ haematoxylin and eosin.

${ }^{*}$ Reciprocal titre. 
Table 2 Complement fixation tests with rabbit sera against $C$ jejuni and campylobacter like organisms

\begin{tabular}{lll}
\hline Rabbit antiserum & Antigen & \\
\cline { 2 - 3 } & C jejuni & $\begin{array}{l}\text { Campylobacter like } \\
\text { organisms }\end{array}$ \\
\hline$v$ C jejuni & 32 \\
$v$ Campylobacter like & $64^{*}$ & 64 \\
\hline organism & $<2$ & \\
\hline
\end{tabular}

${ }^{*}$ Reciprocal titre.

or, more importantly, by culture of the organisms $(90 \%)$. There were also strong positive correlations between gastritis and the presence of complement fixing antibody (90\%) and bacterial agglutinins $(79 \%)$. It is interesting to note that all the patients with abnormal histology had a positive culture or antibody or both. In addition, there was a positive correlation between histologically normal gastric mucosa and failure to grow the organism or detect antibody.

A recent retrospective study of spiral organisms in the stomach showed a significant association between the presence of spiral bacteria and histological gastritis. ${ }^{6}$ In that study the organism was identified histologically in $54 \%$ of the subjects examined-an identical figure to our study. Nevertheless, it is clear that simple culture techniques are a more sensitive method of showing the organism and that serological methods can provide reliable presumptive evi-
Table 5 Antibodies to the camplyobacter like organism in sera from antenatal patients and blood donors

\begin{tabular}{lll}
\hline Sera & $\begin{array}{l}\text { CFT } \\
\geqq 1 / 4\end{array}$ & $\begin{array}{l}\text { Agglutination titre } \\
\geqq 1 / 10\end{array}$ \\
\hline $\begin{array}{ll}\text { Antenatal patients }(\mathrm{n}=100) \\
\text { Blood donors }(\mathrm{n}=50)\end{array}$ & 1 & 5 \\
\hline
\end{tabular}

CFT $=$ complement fixation titre

dence of presence of this campylobacter like organism on the gastric mucosa.

The organisms were identified on the surface of the mucosa in the layer of mucin and in the gastric pits; there was no evidence of invasion of the tissues, although this would be difficult to detect histologically. The frequent presence of antibody in the culture positive patients, however, implies that tissue invasion occurs.

Warren and Marshall ${ }^{2}$ found a positive correlation between the presence of the organsim and active gastritis, but the association with inactive gastritis was less pronounced. Our data fail to confirm this observation as the organism appears to be similarly correlated with both active and inactive gastritis. There was no difference either between the superficial and atrophic gastritis groups, although the number in the latter category was small. The important question is the nature of the association between the campylobacter like organism and a histologically abnormal gastric mucosa. It may be that

Table 3 Antidbodies in patients with and without positive cultures

\begin{tabular}{|c|c|c|c|c|c|c|c|c|}
\hline & \multicolumn{8}{|c|}{ Complement fixation titre } \\
\hline & $<2^{*}$ & 2 & 4 & 8 & 16 & 32 & & \\
\hline \multirow{4}{*}{$\begin{array}{l}\text { Culture positive (31) } \\
\text { Culture negative (19) }\end{array}$} & 5 & 4 & 3 & 9 & 7 & 3 & & \\
\hline & 14 & 1 & 2 & 1 & 1 & & & \\
\hline & \multicolumn{8}{|c|}{$H$ agglutination titre } \\
\hline & $<10$ & 10 & 20 & 40 & 80 & 160 & 320 & 640 \\
\hline $\begin{array}{l}\text { Culture positive ( } 31) \\
\text { Culture negative (19) }\end{array}$ & $\begin{array}{r}6 \\
15\end{array}$ & $\begin{array}{l}3 \\
2\end{array}$ & 4 & $\begin{array}{l}4 \\
1\end{array}$ & $\begin{array}{l}4 \\
1\end{array}$ & 8 & 1 & 1 \\
\hline
\end{tabular}

* Reciprocal titre

Numbers in parentheses $=$ numbers of patients.

Table 4 Antibodies in patients with normal and abnormal biopsies

\begin{tabular}{|c|c|c|c|c|c|c|c|c|}
\hline & \multicolumn{8}{|c|}{ Complement fixation titre } \\
\hline & $<2$ & 2 & 4 & 8 & 16 & 32 & & \\
\hline \multirow[t]{3}{*}{$\begin{array}{l}\text { Gastritis present (29) } \\
\text { Normal (15) }\end{array}$} & $\begin{array}{r}3 \\
13\end{array}$ & $\begin{array}{l}3 \\
1\end{array}$ & $\begin{array}{l}4 \\
1\end{array}$ & 10 & $\frac{6}{-}$ & 3 & & \\
\hline & \multicolumn{8}{|c|}{$H$ agglutination titre } \\
\hline & $<10$ & 10 & 20 & 40 & 80 & 160 & 320 & 640 \\
\hline $\begin{array}{l}\text { Gastritis (29) } \\
\text { Normal (15) }\end{array}$ & $\begin{array}{r}6 \\
14\end{array}$ & $\frac{3}{-}$ & $\frac{4}{-}$ & $\frac{5}{-}$ & $\frac{3}{-}$ & $\begin{array}{l}6 \\
1\end{array}$ & 1 & 1 \\
\hline
\end{tabular}

Numbers in parentheses $=$ numbers of patients. 
the organism is simply a commensal but, on the other hand, it may have a pathogenic role in the development of gastritis. The low frequency with which antibody was detected in groups of normal individuals (antenatal patients and blood donors) suggests that antibody and presumably the organism occur much less commonly in patients without gastrointestinal symptoms. The finding of antibody in culture positive patients suggests that it invades the tissues, although there was no correlation between the degree of gastritis and the level of the antibody response. Further studies to attempt to answer this important question are underway.

We are particularly indebted to Dr JP Miller and Dr PJ Whorwell for their help in this study.
References

' Freedberg AS, Barron LE. The presence of spirochetes in human gastric mucosa. Am J Dig Dis 1940;7:443-445.

${ }^{2}$ Warren JR. Unidentified curved bacilli on gastric epithelium in active chronic gastritis. Letter. Lancet 1983;i: 1273.

${ }^{3}$ Marshall BJ. Unidentified curved bacilli on gastric epithelium in active chronic gastritis. Letter. Lancet 1983; i:1273-5.

4 Whitehead R. Mucosal biopsy of the gastrointestinal tract. 2nd ed. Philadelphia: WB Saunders, 1979.

5 Jones DM, Elridge J, Dale BAS. Serological response to Campylobacter jejuni/coli infection.J Clin Pathol 1980;33:767-9.

- Rollason TP, Stone J, Rhodes JM. Spiral organisms in endoscopic biopsies of the human stomach. J Clin Pathol 1984;37:23-26.

Requests for reprints to: Dr DM Jones, Public Health Laboratory, Withington Hospital, Manchester M20 8LR, England. 